\title{
Correlation optics in progress: introduction to the feature issue
}

Angelsky, Oleg V.; Desyatnikov, Anton S.; Gbur, Gregory J.; Hanson, Steen Grüner; Miyamoto, Yoko; Szoplik, Tomasz

\section{Published in:}

Applied Optics

Link to article, DOI:

10.1364/AO.53.0CO259

10.1364/AO.53.000CO1

Publication date:

2014

Document Version

Publisher's PDF, also known as Version of record

Link back to DTU Orbit

Citation (APA):

Angelsky, O. V., Desyatnikov, A. S., Gbur, G. J., Hanson, S. G., Miyamoto, Y., \& Szoplik, T. (2014). Correlation optics in progress: introduction to the feature issue. Applied Optics, 53(10), CO259-CO260.

https://doi.org/10.1364/AO.53.0CO259, https://doi.org/10.1364/AO.53.000CO1

\section{General rights}

Copyright and moral rights for the publications made accessible in the public portal are retained by the authors and/or other copyright owners and it is a condition of accessing publications that users recognise and abide by the legal requirements associated with these rights.

- Users may download and print one copy of any publication from the public portal for the purpose of private study or research.

- You may not further distribute the material or use it for any profit-making activity or commercial gain

- You may freely distribute the URL identifying the publication in the public portal

If you believe that this document breaches copyright please contact us providing details, and we will remove access to the work immediately and investigate your claim 


\title{
Correlation optics in progress: introduction to the feature issue
}

\author{
Oleg V. Angelsky, ${ }^{1, *}$ Anton S. Desyatnikov, ${ }^{2}$ Gregory J. Gbur, ${ }^{3}$ Steen G. Hanson, ${ }^{4}$ \\ Yoko Miyamoto, ${ }^{5}$ and Tomasz Szoplik ${ }^{6}$ \\ ${ }^{1}$ Chernivtsi National University, 2 Kotsyubinsky Street, Chernivtsi 58012, Ukraine \\ ${ }^{2}$ Nonlinear Physics Centre, Research School of Physics and Engineering, \\ The Australian National University, Canberra ACT 0200, Australia \\ ${ }^{3} 7519$ Greylock Ridge Road, Matthews, North Carolina 28105, USA \\ ${ }^{4}$ DTU Fotonik, 4000 Roskilde, Denmark \\ ${ }^{5}$ The University of Electro-Communications, Chofugaoka, Chofu, Tokyo 182-8585, Japan \\ ${ }^{6}$ University of Warsaw Krakowskie Przemiescie 26/28, Warsaw 00-927, Poland \\ ${ }^{*}$ Corresponding author: angelsky@itf.cv.ua \\ Received 3 March 2014; \\ posted 3 March 2014 (Doc. ID 207428); published 31 March 2014
}

\begin{abstract}
This feature issue of Applied Optics contains a series of selected papers reflecting recent progress of correlation optics and showing, in part, the trend from micro-optics to nano-optics.

OCIS codes: (110.0113) Imaging through turbid media; (020.6580) Stark effect. http://dx.doi.org/10.1364/AO.53.0CO259
\end{abstract}

Correlation optics [1] is among the most attractive and promising areas of modern optics and photonics. Being generically connected with the concept of partial coherence and partial polarization [2], correlation optics touches upon such fundamental domains as singular optics and fractal optics, as well as applications, including optical diagnostics in material science and industrial control, optical metrology, and biomedical applications of lasers. Recent progress in correlation optics has appeared in several important events and is reflected in papers included in this feature issue. First, the concepts and experimental techniques of partial coherence and partial polarization are actively involved within singular optics [3], being important for the problem of spin-to-orbital conversion as well as for deriving reliable algorithms for construction of singular skeletons of complex optical fields. Second, investigations of so-called internal optical flows have led to the use of ensembles of (gold) nanoparticles as unique highly sensitive probes for highlighting the intimate structure of light fields and their behavior depending on the degree of coherence and states of polarization of their components. Spatial modulation of the time-averaged Poynting vector taking place in such fields can subsequently be used for construction of polarization manipulators and traps for controlling not only microparticles but nanoparticles as well, which is of vital importance for further progress of nanophotonics and nanophysics. These investigations are also of fundamental importance. Namely, elaboration of spin energy flows in circularly polarized inhomogeneous light fields leads to a deeper understanding of the nature of spin of a photon as the angular momentum is generated by circulated energy flow in the wave field of a photon. Comparison of computations of the angular momentums following Dirac and within the framework of classical electrodynamics shows that the spin of a photon corresponds to the angular momentum intrinsic to a classical circularly polarized wave.

In the past 20 years, since 1993, 11 biannual international conferences devoted to this large area of research and development have been held under 
the aegis of world-leading optical communities (SPIE, OSA, ICO, EPS, EOS). This feature issue of Applied Optics contains a series of selected papers reflecting recent progress in correlation optics and showing, in part, the trend from micro-optics to nano-optics. Conventionally, the papers might be distributed in the following topics:

- Informative content of statistical optical fields, including optical chaos, singular optics, polarization optics, and coherence.

- Optical correlation devices based on diffraction optical elements, including optical and digital holography, fractal optics, and optical sensors.
- Optical correlation diagnostics, interferometry, and microscopy of rough surfaces and random media.

- New applications of correlation optics in biology and medicine.

\section{References}

1. O. V. Angelsky, P. V. Polyanskii, and C. V. Felde, "The emerging field of correlation optics," Opt. Photon. News 23(4), 25-29 (2012).

2. Feature Issue on "Correlation Optics," Appl. Opt. 51, C1-C231 (2012).

3. G. Gbur and T. D. Visser, "The structure of partially coherent fields," Prog. Opt. 55, 285-341 (2010). 